Available online at: www.cahiersagricultures.fr

\title{
Oil palm crop: state and gaps of research and technological development at global scale, Latin America and Mexico
}

\author{
Luz del Carmen Lagunes-Espinoza ${ }^{1}$ (D), César Jesús Vazquez-Navarrete ${ }^{1, *}$ (D, \\ Joaquín Alberto Rincón-Ramirez ${ }^{1, *}$ (D) and Kathleen E. Halvorsen ${ }^{2}$ (B) \\ ${ }^{1}$ Colegio de Postraduados, Campus Tabasco, Periferico Carlos A. Molina s/n, H. Cárdenas, Tabasco 86500, Mexico \\ 2 AOB, Social Sciences MTU, 1400 Townsend Drive, Houghton, Michigan 49931, USA
}

\begin{abstract}
Oil palm plantations face important challenges in terms of balancing agricultural productivity and environmental sustainability. This research synthesis aims to answer key questions regarding the state and knowledge gaps of oil palm (OP) research and technological development (R\&D) at a global scale, in Latin America and in Mexico, using all Web of Science ${ }^{\circledR}$ databases and agriculture categories and time spans between 1960 and 2018. Three thousand nine hundred and forty-eight publications were analysed. The research themes started with the generation of agronomic knowledge in 1960. Since 1963, studies in Latin America have focused on yield improvement; since 2010, topics related to agroecology, product quality, health issues, biodiversity, conservation impacts, and biofuel uses have been widely integrated, although some relevant themes are lacking. In addition, considering the high domestic demand for crude palm oil and great available natural resources, few Mexican institutions have participated in publications registered in Web of Science (WOS) on this topic. This research proposes a quick exploratory and reliable instrument for evaluating the agronomic interest of any agricultural production system.
\end{abstract}

Keywords: research synthesis / evidence-based decision making / R\&D

Résumé - Le palmier à huile : état des plantations et défis de la recherche et du développement technologique à l'échelle mondiale, en Amérique latine et au Mexique. Les plantations de palmier à huile sont confrontées à des défis importants en termes d'équilibre entre productivité agricole et durabilité environnementale. Cette synthèse a pour objectif de répondre aux principales questions relatives à la recherche et au développement technologique $(\mathrm{R} \& \mathrm{D})$ que pose la culture du palmier à huile à l'échelle mondiale, en Amérique latine et au Mexique, en utilisant les bases de données du Web of Science ${ }^{\circledR}$ sur l'agriculture entre 1960 et 2018. Trois mille neuf cent quarante-huit publications ont été analysées. Dans les années 1960, les recherches ont commencé sur des thématiques agronomiques. En Amérique latine, à partir de 1963, les études ont porté sur l'amélioration des rendements. Depuis 2010, les thèmes liés à l'agroécologie, à la qualité des produits, aux problèmes sanitaires, aux biocarburants, et aux impacts sur la biodiversité et l'environnement ont été largement intégrés. Mais certains thèmes importants sont absents. De plus, il apparaît que peu d'institutions mexicaines participent aux publications enregistrées dans le Web of Science sur le palmier, alors qu'il y a une forte demande intérieure pour l'huile de palme et de grandes ressources naturelles disponibles. Notre démarche propose un instrument d'exploration rapide et fiable pour évaluer les thèmes d'intérêt agronomique de tout système de production agricole.

Mots clés : recherche de synthèse / prise de décision basée sur des preuves / R\&D

*Corresponding authors: jrincon@colpos.mx; vcesar@colpos.mx 


\section{Introduction}

The global consumption of crude palm oil (CPO) has increased based on the high population growth rates since the 1960s; it surpassed that of soybean oil in 2007 and became the global dominant vegetable oil. CPO demand is expected to increase by different driving forces, e.g., food consumption patterns, energy policies, and improved quality of life. A consensus has been reached that this demand can be met by improving yields, increasing sustainable production practices, and expanding plantations that prevent the conversion of high conservation value areas. Scientific knowledge plays a fundamental role in addressing this global challenge by improving our understanding of interactions between oil palm (OP) and surrounding landscapes and developing technology and better practices for several different locations (Hoffmann et al., 2017; Murphy, 2014).

OP expansion occurs in humid tropical regions in Asia, Africa, and America; more than $50 \%$ of the available and suitable area could be located in South America, Central America, and Mexico (Furumo and Aide, 2017).

Mexican domestic consumption of palm oil was 650 thousand tons in 2018. Although $80 \%$ was supplied from imports, domestic cropped area increased over the last 20 years from 10000 to 77000 hectares. Mexico has a potential of 8.9 million hectares for OP production, and most could be established on grassland (SAGARPA, 2017; SIAP, 2019). This potential expansion requires strategic information based on scientific knowledge to achieve sustainable production. OP expansion should develop successfully in areas where scientific knowledge is available to overcome most of the limiting production factors and meet environmental criteria, food chain accessibility, and local development demands.

This study aims to identify the relationship between the historical production of oil palm and the spatial dynamics of development and knowledge production. Some questions have arisen from OP expansion at a global scale, specifically in Latin America and Mexico: i.e., a) what countries are generating research and development (R\&D) on this crop, b) what topics are being studied, c) how are these topics changing, d) what institutions are carrying out this $R \& D$, and e) where does Mexico fit in comparison to Latin American countries and other producing countries. A review of scientific publications was carried out to respond to these core questions and was used to analyse the knowledge created in this specific research area (Pare et al., 2015); a historical and geographical approach was used to link knowledge creation to agricultural development dynamics. A comprehensive understanding of this baseline information by considering different disciplines, such as agronomical, processing, social and environmental disciplines, is a key starting point (Padfield et al., 2019; Woittiez et al., 2017).

\section{Methodology}

To achieve our research goal, we reviewed the existing literature from different contexts (Cooper et al., 2009; Hood and Wilson, 2001; Pare et al., 2015; Wyborn et al., 2018) and developed an approach that included 9 phases.
1 Search strategy: this search was performed in Web of Science (WoS), and all databases were consulted. In WoS, three keywords related to OP, "oil palm" OR "Elaeis guineensis" OR "African palm", were selected by using the TOPIC field. OP-related publications were selected between 1960 and 2017.

2 Revision of the preliminary dataset: a revision of the preliminary results by identifying the main research categories of OP knowledge using WoS analyzing tools.

3 Criteria selection: Three criteria to select publications were used: i) papers that were classified as Agriculture according to the WoS classification system; ii) papers that had an abstract or general description; and iii) papers that had basic information related to the main research topics.

4 Main research topics: Based on our research objectives, two sets of keywords related to core performance indicators classified into three category levels were proposed (Tab. 1).

5 Algorithm selection: Considering the main research topics, publications were classified by using the following decision tree (Fig. 1). For publications with several research topics that were classified based on their relation to a yield-oriented indicator of OP, the classification was carried out in an Excel program.

6 Analysis unit: A dataset of publications related to OP was generated. A total of 863 publications were not considered in the analysis since they were duplicated and had missing information. The final dataset based on agricultural research areas consisted of 3948 bibliography references and seven tag fields for analysis: title, abstract, authors, keywords, country, author information (e.g., institution, country), and year of publication.

7 Exploratory analysis: The analysis of OP knowledge was exploratory, and descriptive statistics were used to analyze topics and indicators of the agronomic management of OP, and the results were summarized in figures. Series analyses were also performed to identify changes and tendencies in the different topics during the studied period. Some associations were tested to shed light on the interactions between outcomes and OP knowledge results.

8 Results outline: The results were organized based on the research questions.

9 Recommendations for decision-making: A "storyline" was provided for decision-makers to clarify the problems and opportunities identified based on OP agronomic practices designed to improve yield and other important topics.

\section{Results}

\subsection{Description of the dataset}

In total, 9886 publications were identified in the preliminary revision phase, of which 2201 were patents. Considering the research area classification system of WoS, 4731 publications were identified in agriculture, 3296 were identified in plant science, 432 were identified in biodiversity and conservation and 651 were identified in environmental science and ecology. Between categories, 2439 publications were repeated. In 1960, a total of 2 publications were 
Table 1. Keywords used for classification of R\&D publications.

Tableau 1. Mots clés utilisés pour la classification des publications de R\&D.

\begin{tabular}{lll}
\hline Category & \multicolumn{2}{c}{ Keywords } \\
\cline { 2 - 3 } & Indicators & Description \\
\hline $\begin{array}{l}\text { Agronomy approach (Yield oriented) } \\
\text { Other topics related to yield improvement }\end{array}$ & $\begin{array}{l}\text { Yield, bunch, FFB, oil } \\
\text { Other performance indicators }\end{array}$ & $\begin{array}{l}\text { Breeding, genetic, fertilisation, nitrogen, soil, disease, } \\
\text { pest, irrigation, drainage, water use, physiology (leaf } \\
\text { area index, plant development, photosynthesis, } \\
\text { transpiration, sap flux, drought, flooding) } \\
\text { Biofuel, health, biodiversity, conservation, } \\
\text { environment, sustainability, and others }\end{array}$ \\
\hline
\end{tabular}

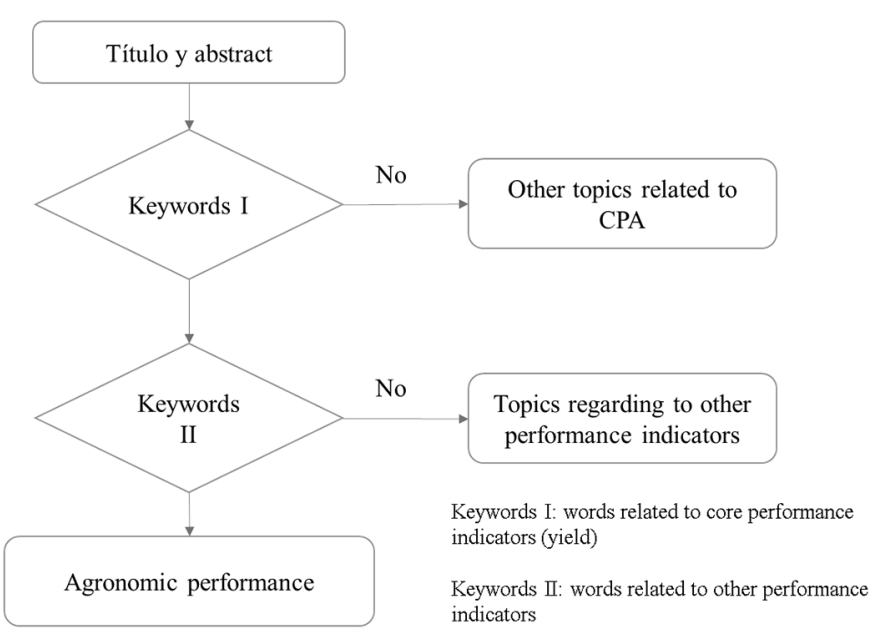

Fig. 1. Tree decision for classifying publications by performance indicator.

Fig. 1. Arbre de décision pour classer les publications par indicateur de performance.

registered, while in 2017, 2284 publications were registered. From a total of 476 universities, research centres, and private corporations, OP has been researched on a global scale, with six institutions generating more than 100 publications each from 1960-2017 and only three generating the most significant number of publications: Putra Malaysia University, French Agricultural Research Center for Development (CIRAD) and the Malaysian Palm Board.

In the agriculture category, 4731 publications were used in the analysis. A typical evolution was observed for publications within all categories: an increment of the number of publications started from 2010, with the number shifting from 150 publications/year to more than 400 publications in 2017 .

In total, 547 patents were registered; they consisted of different themes, such as processed oil palm fresh fruit bunches (FFBs) (Ng et al., 2017), fertilizer and soil amelioration agents based on dried-empty-bunch ashes (Abdullah et al., 2017), pesticides (Fan et al., 2017), or yield prediction (Ong et al., 2017).

\subsection{Which countries are generating R\&D on OP?}

On a global scale, OP site studies are mainly concentrated in three countries: Malaysia and Indonesia in Southeast Asia, and Nigeria in Africa. In Latin America, most OP knowledge is produced in Brazil and Colombia (Fig. 2).

\subsection{Which research themes are being studied worldwide?}

There are many publications on OP physiology (18.3\%), covering physiological and metabolic functions. Also important are basic genetic research and applied research by classic and molecular genetic improvement (18.9\%); another critical group of publications focus on the causal relationships among pests, diseases, and OP productivity $(14.8 \%)$. Since 2005 , a greater understanding of our complex and interconnected world has led to an increase in publications on the impacts of OP and sustainability (13.9\%), the effect of OP on biodiversity and conservation $(9.2 \%)$, the use of OP as an energy feedstock $(3.2 \%)$, and the impact of palm oil products on health issues (2.8\%) (Fig. 3).

Since 2010, many studies have been performed on the effect of OP expansion on the biodiversity and conservation of forest areas, grasslands, and soils and the impact of OP consumption, the development of new products, the sustainable management of OP, its use as a bioenergy feedstock, and its impacts on human health (Fig. 4).

\subsection{What R\&D has been generated in Latin America?}

This study identified 339 publications and 15 patents in the Latin American region. Brazil and Colombia accounted for the most extensive acreage of OP and the primary number of publications referred to study sites in their territories $(>60)$, followed by Costa Rica, Ecuador, Peru, Venezuela, Mexico, and Panama (Fig. 2). Recently, environmental studies have increased in this region (19.7\%), and some research subjects have been based on OP production and the challenge of including the agroecology concept for environmental impact reduction, not only for OP used as food but also as bioenergy feedstock (Castellanos-Navarrete and Jansen, 2017). Other research themes focused on the impacts and interactions, such as the expansion of OP and its social and economic effects (14.1\%) (Bennett et al., 2018; Gonzalez-Salazar et al., 2017), the impact of fertilization (8.1\%) (Bastos de Matos et al., 2017) and genetic improvements (7.0\%) (De Farias Neto et al., 2013; Moreno-Caicedo and Bastidas-Pérez, 2017; Sousa et al., 2016), the response of physiological parameters to abiotic factors (gas exchange, water use, and foliar area) (3.5\%) 


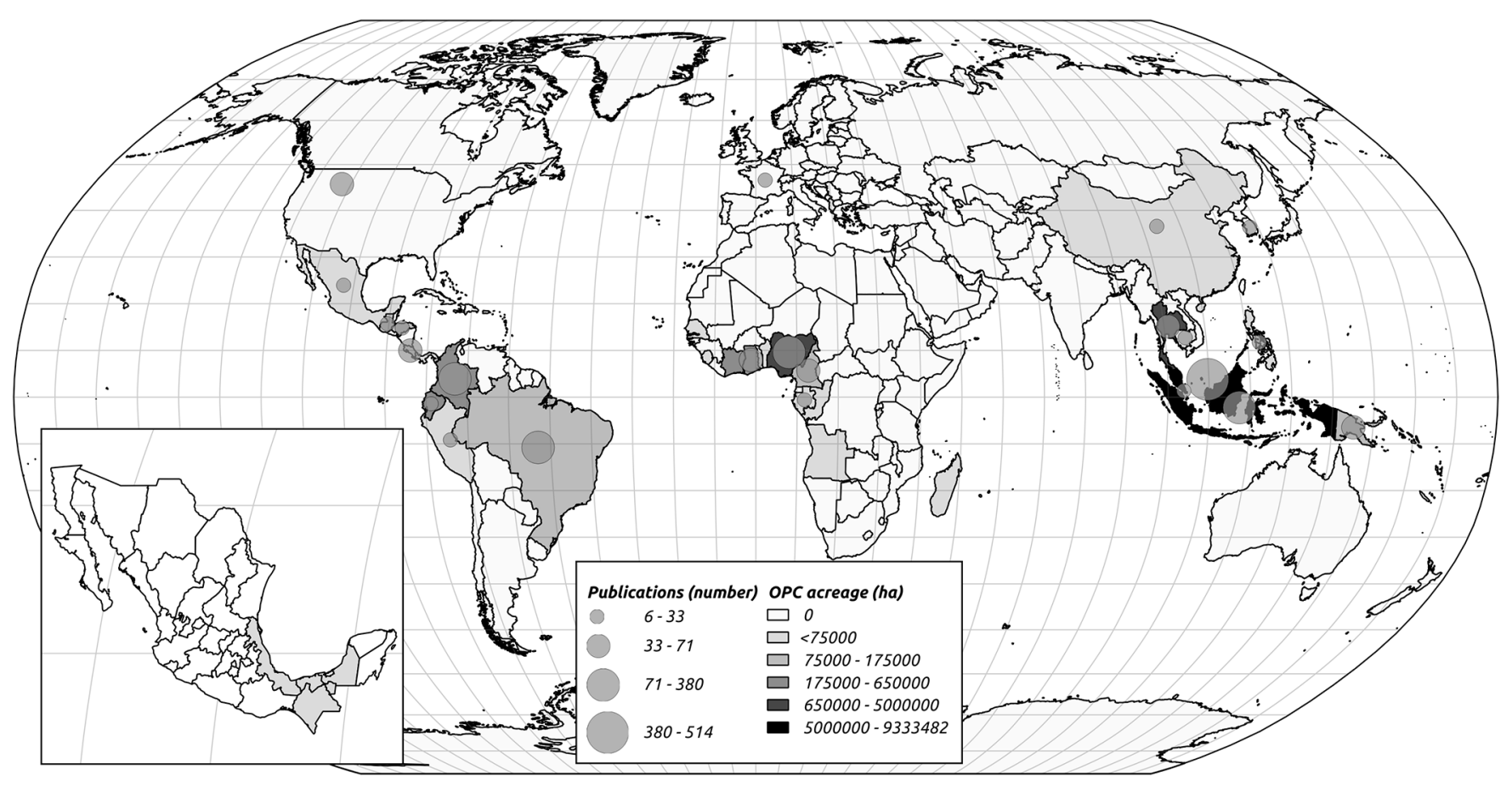

Fig. 2. Oil Palm Crop acreage and number of publications on oil palm crop by country in 2017 (with a zoom on Mexico).

Fig. 2. Surfaces cultivées en palmier à huile et nombre de publications sur cette culture par pays en 2017 (avec un zoom sur le Mexique).

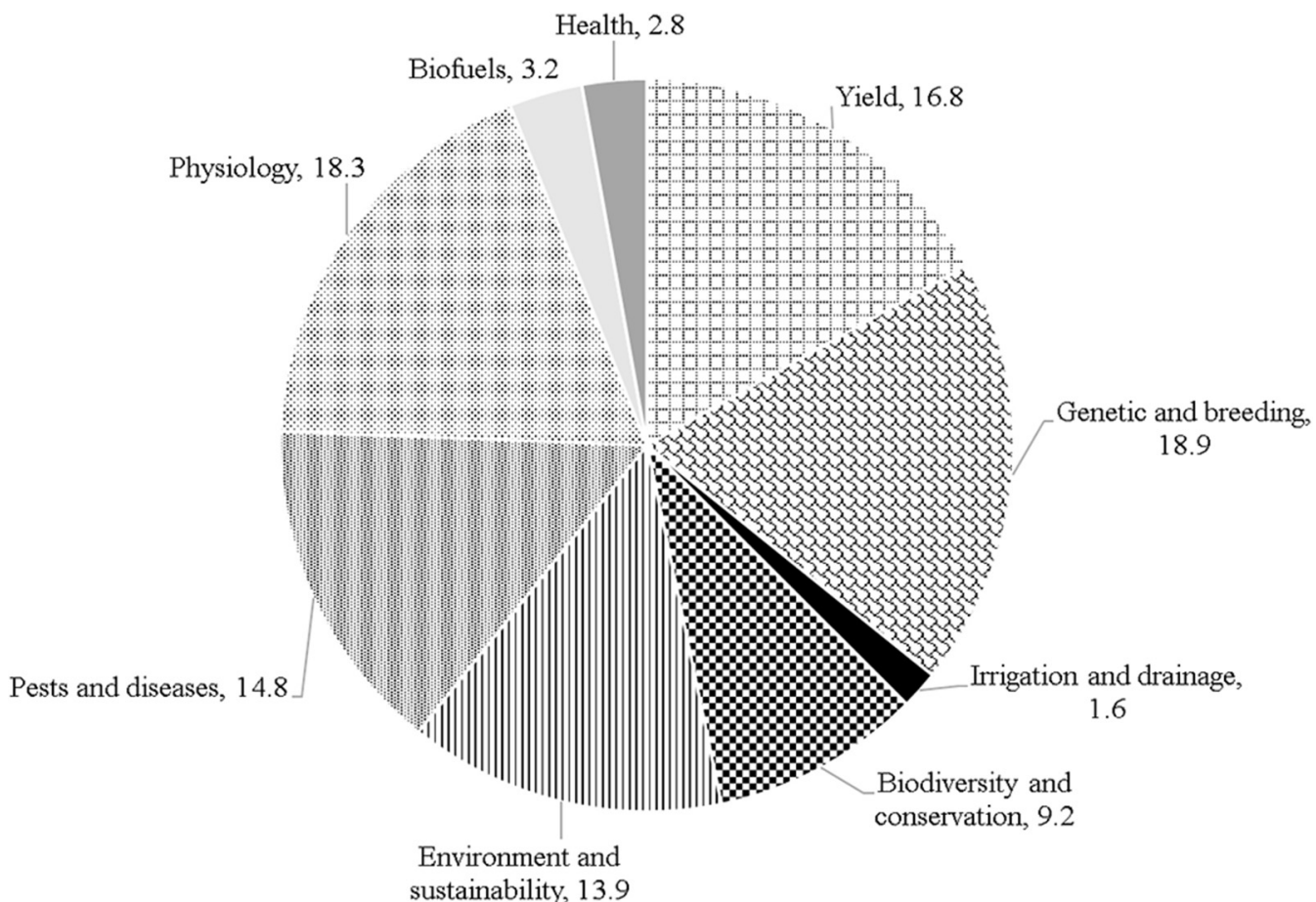

Fig. 3. Frequency (\%) of main research themes on OP during 1960-2017.

Fig. 3. Fréquence (\%) des principaux thèmes de recherche sur le palmier à huile entre 1960 et 2017. 


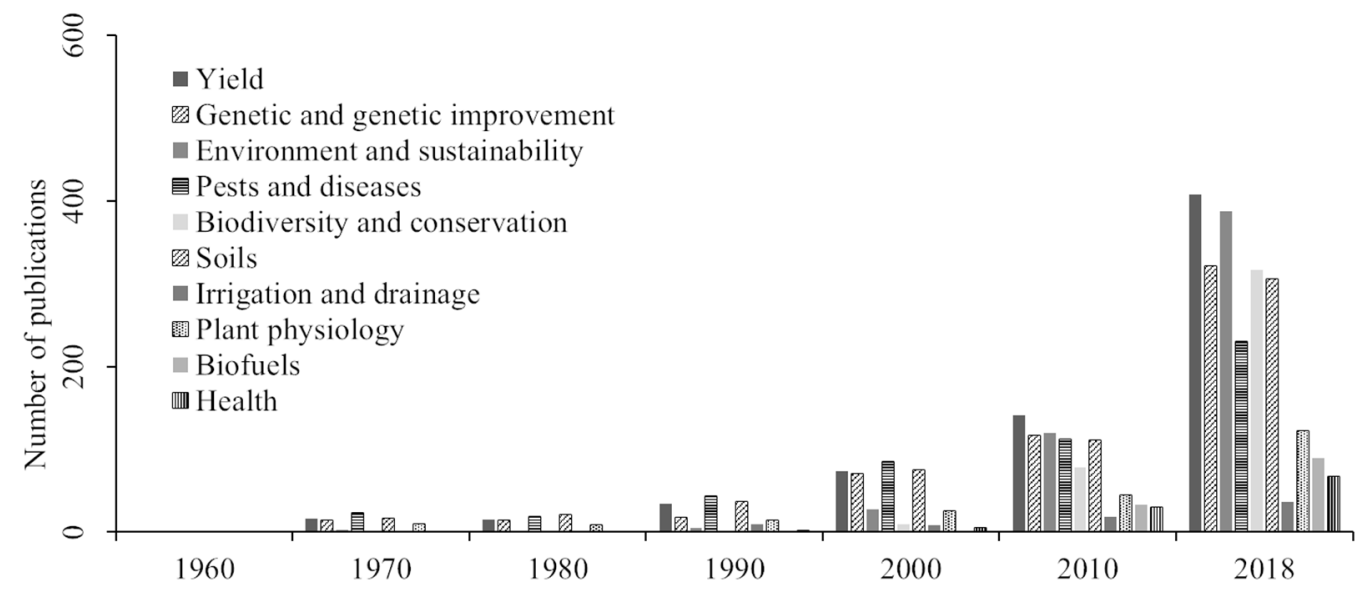

Fig. 4. Evolution of research themes on OP during 1960-2018.

Fig. 4. Évolution des thèmes de recherche sur le palmier à huile entre 1960 et 2018.

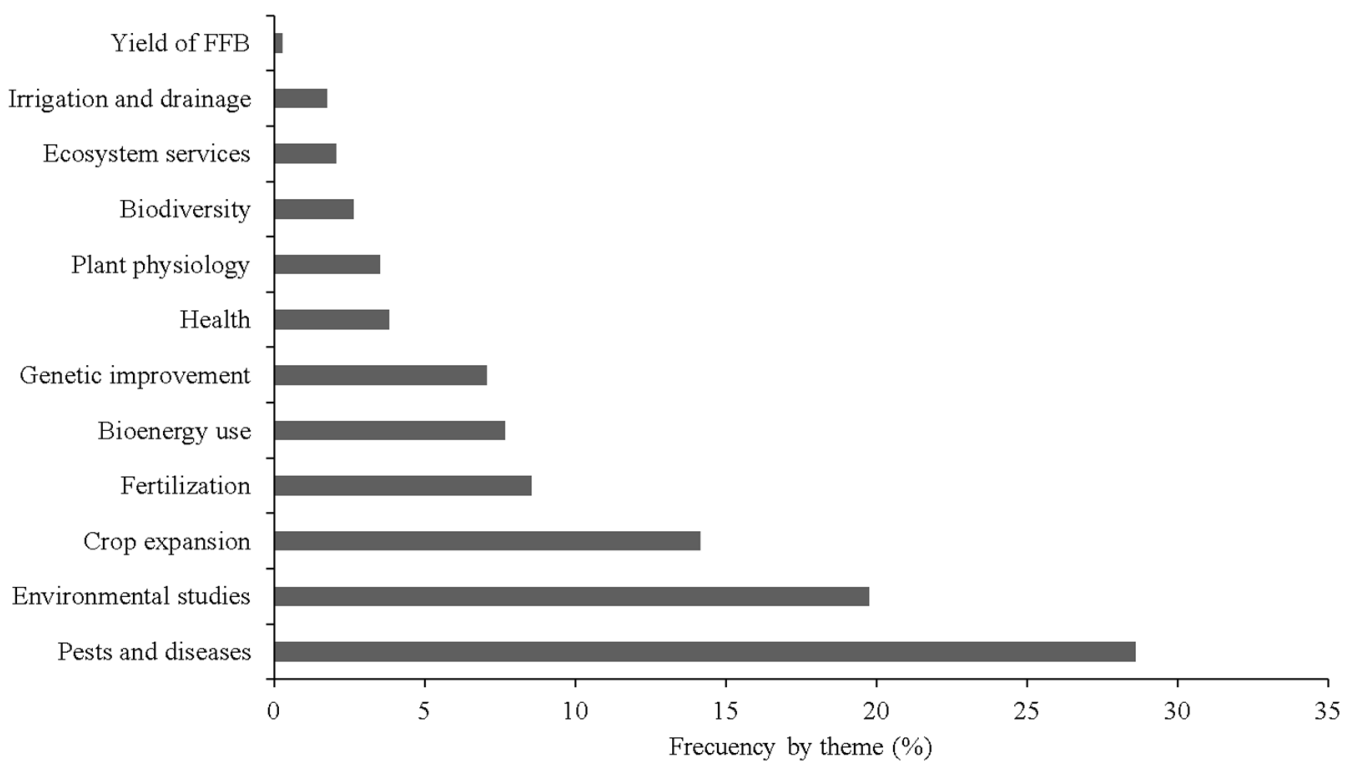

Fig. 5. Frequency (\%) of the main research themes on OP in Latin America during 1960-2018.

Fig. 5. Fréquence (\%) des principaux thèmes de recherche sur le palmier à huile en Amérique latine entre 1960 et 2018.

(Murugesan et al., 2017; Rivera Mendez et al., 2012), the effect of irrigation and drainage $(1.7 \%)$, yield of FFB $(0.2 \%)$ (Contreras et al., 2012; De Farias Neto et al., 2013), the use of OP as a bioenergy feedstock (7.6\%) (Aristizabal et al., 2016; Cardoso et al., 2017), and the impacts on biodiversity $(2.6 \%)$ (Alonso-Rodriguez et al., 2017; Knowlton et al., 2017) and ecosystem services (2.0\%) (Frazão et al., 2013; Lavelle et al., 2014). Other studies also focused on the impact of palm oil on human consumption by characterizing oil products and health conditions (3.8\%) (Irias-Mata et al., 2017, Sandoval-Garcia et al., 2016) (Fig. 5).

\subsection{What is the OP R\&D baseline in Mexico?}

The introduction of OP in Mexico started in 1980 and recently accounted for 90118 ha distributed in four states: Campeche, Chiapas, Tabasco, and Veracruz (SIAP, 2019)
(Fig. 2). Most of the production is used for food, and $32 \%$ is associated with other industrial uses (FAO, 2018). The number of publications found in the WoS databases is limited (10 papers), and the research subjects are disconnected. Publications dealing with the social impacts of OPs (Castellanos-Navarrete and Jansen, 2018), the effect of the production and expansion of OPs on land-use change and biodiversity (Aguilar-Gallegos et al., 2015; Castellanos-Navarrete and Jansen, 2015; Furumo and Aide, 2017; Lin et al., 2012), and the use of environmentally friendly and less impacting practices in Chiapas have been published (Castellanos-Navarrete and Jansen, 2018). One article on methods of using palm oil as a biofuel (Sandoval-Garcia et al., 2016) and two papers on pests and diseases, Raoiella indica Hirst (Otero-Colina et al., 2016) and Calyptocephala gerstaeckeri Boheman (Cordova-Ballona and Sanchez-Soto, 2008), were published. 


\subsection{Which institutions have carried out R\&D on OP in Mexico?}

Mexican institutions found in the WoS that have performed research on OP include the Instituto Nacional de Investigaciones Forestales, Agricolas and Pecuarias (INIFAP) and Colegio de Postgraduados, Campus Tabasco. Other institutions that have carried out social and environmental research on $\mathrm{OP}$ in Mexico include the Universidad Autonoma Chapingo, Universidad Autonoma de Chiapas, el Colegio de la Frontera Sur and Universidad Juarez Autonoma de Tabasco. Most of these institutions are publicly funded and the performed OP research was based on their location.

\section{Discussion}

The global R\&D of OP is associated with different scientific knowledge platforms, and such platforms allow researchers to determine the current state of a particular research subject at any temporal and spatial scale, which was confirmed in this study and in other research (Bartol et al., 2014; Scherm et al., 2014; Wyborn et al., 2018).

This study highlighted the relationship between the number of publications/year and the expansion of oil palm plantations in countries such as Malaysia, Indonesia, Colombia, Brazil, and Mexico, as brought to light by Abrizah (2012).

As argued by other scholars, such as Castellanos-Navarrete and Jansen (2017), this study also showed a change in the patterns in thematic research areas, based on issues raised regarding oil palm development and its responsible consumption, such as the certification and creation of the Roundtable on Sustainable Palm Oil (RSPO), production of biofuel, etc.

Based on the analysis of previous research, this study also provided practical knowledge to estimate research performance indicators, such as the number of publications per country, per scientific staff, and per core research subject. Future studies could implement this strategic knowledge to foster a decision-making process based on evidence.

\section{Conclusions}

The analysis of global and Latin American scientific knowledge on the R\&D of OP and the comparison with the knowledge from Mexico revealed a R\&D gap on agronomic and socioecological topics and very few scientific products generated (number of articles and patents), which might be explained by the few research institutions involved in these research areas in Mexico. These results are inconsistent with those concerning leading OP countries. Although several research areas were identified and are similar to the ones found in other studies (Abrizah, 2012), Mexican R\&D is focused on three areas. Thus, it is recommended to foster agronomy, technological innovation, and socioecological issues. To encourage OP R\&D in Mexico, effective public policies are required to incentivize cooperation between key stakeholders, i.e., producers, industry and retailers, to achieve sustainable production and improve the well-being across the food supply chain.

\section{References}

Abrizah A. 2012. A bibliometric study on the worldwide research productivity of scientists in Elaeis guineensis Jacq. and Elaeis oleifera. Journal Oil Palm Research 24: 1459-1472.

Abdullah MNB, Mohamad YMS, Sharom ML, Zulkafli MZB. 2017. Composite useful as a fertilizer and a soil amelioration agent, comprises nanoporous zeolite and oil palm bunch ash. Patent.

Aguilar-Gallegos N, Munoz-Rodriguez M, Santoyo-Cortes $\mathrm{H}$, Aguilar-Avila J, Klerkx L. 2015. Information networks that generate economic value: A study on clusters of adopters of new or improved technologies and practices among oil palm growers in Mexico. Agricultural Systems 135: 122-132. https://doi.org/ 10.1016/j.agsy.2015.01.003.

Alonso-Rodriguez AM, Finegan B, Fiedler K. 2017. Neotropical moth assemblages degrade due to oil palm expansion. Biodiversity and Conservation 26: 2295-2326. https://doi.org/10.1007/ s10531-017-1357-1.

Aristizabal V, Garcia CAV, Cardona CA. 2016. Integrated Production of Different Types of Bioenergy from Oil Palm Through Biorefinery Concept. Waste and Biomass Valorization 7: 737-745. https://doi.org/10.1007/s12649-016-9564-7.

Bartol T, Budimir G, Dekleva-Smrekar D, Pusnik M, Juznic P. 2014. Assessment of research fields in Scopus and Web of Science in the view of national research evaluation in Slovenia. Scientometrics 98: 1491-1504. https://doi.org/10.1007/s11192-013-1148-8.

Bastos de Matos GS, Fernandes AR, Salvador Wadt PG, de Abreu Pina AJ, Franzini VI, Nascimento Ramos HM. 2017. The use of DRIS for nutritional diagnosis in oil palm in the State of Para. Revista Brasileira De Ciencia Do Solo 41: e0150466. https:// doi.org/10.1590/18069657rbcs20150466.

Bennett A, Ravikumar A, Cronkleton P. 2018. The effects of rural development policy on land rights distribution and land use scenarios: The case of oil palm in the Peruvian Amazon. Land Use Policy 70: 84-93. https://doi.org/10.1016/j.landusepol.2017.10.011.

Cardoso A, Laviola BG, Santos GS, de Sousa HU, de Oliveira HB, Veras LC, et al. 2017. Opportunities and challenges for sustainable production of A. aculeata through agroforestry systems. Industrial Crops and Products 107: 573-580. https://doi.org/10.1016/j. indcrop.2017.04.023.

Castellanos-Navarrete A, Jansen K. 2015. Oil palm expansion without enclosure: smallholders and environmental narratives. Journal of Peasant Studies 42: 791-816. https://doi.org/10.1080/ 03066150.2015 .1016920$.

Castellanos-Navarrete A, Jansen K. 2017. Why do smallholders plant biofuel crops? The "politics of consent" in Mexico. Geoforum 87: 15-27. https://doi.org/10.1016/j.geoforum.2017.09.019.

Castellanos-Navarrete A, Jansen K. 2018. Is oil palm expansion a challenge to agroecology? Smallholders practising industrial farming in Mexico. Journal of Agrarian Change 18: 132-155. https://doi.org/10.1111/joac.12195.

Contreras ÁP, Cayón G, Corchuelo G. 2012. Models to estimate the bunch dry weight in African oil palm (Elaeis guineensis Jacq.), American oil palm (Elaeis oleifera H.B.K. Cortes) and the interspecific hybrid (E. oleifera x E. guineensis). Agronomía Colombiana 30: 46-51.

Cooper HM, Hedges LV, Valentine JC. 2009. The handbook of research synthesis and meta-analysis. London: Rusell Sage Foundation.

Cordova-Ballona L, Sanchez-Soto S. 2008. Bionomics data and descriptions of the immatures of Calyptocephala gerstaeckeri Boheman (Coleoptera: Chrysomelidae), pest of the oil palm (Elaeis guineensis J.) and camedor palm (Chamaedorea elegans Mart.) (Arecaceae) in Tabasco, Mexico. Neotropical Entomology 37: 674-680. https://doi.org/10.1590/S1519-566x2008000600008. 
De Farias Neto JT, Clement CR, Vilela de Resende MD. 2013. Estimates of genetic parameters and selection gain for fruit production in open-pollinated progenies of peach palm in the State of Para, Brazil. Bragantia 72: 122-126. https://doi.org/10.1590/ S0006-87052013000200002.

Fan Z, Zhu Y, Xu J, Song Y, Zhang Z, Zhang N, et al. 2017. New bromohexahydroindanone useful in preparation of bactericide for bactericidal composition, tobacco flower leaf antiviral agent for antiviral composition, plant activator and pesticide. Patent.

FAO. 2018. Faostat: Crop production. yearly. FAO website: FAO.

Frazão LA, Paustian K, Pellegrino Cerri CE, Cerri CC. 2013. Soil carbon stocks and changes after oil palm introduction in the Brazilian Amazon. Global Change Biology Bioenergy 5: 384-390. https://doi.org/10.1111/j.1757-1707.2012.01196.x.

Furumo PR, Aide TM. 2017. Characterizing commercial oil palm expansion in Latin America: land use change and trade. Environmental Research Letters 12: 024008. https://doi.org/10.1088/ 1748-9326/aa5892.

Gonzalez-Salazar MA, Venturini M, Poganietz WR, Finkenrath M, Leal MRLV. 2017. Combining an accelerated deployment of bioenergy and land use strategies: Review and insights for a postconflict scenario in Colombia. Renewable and Sustainable Energy Reviews 73: 159-177. https://doi.org/10.1016/j.rser.2017.01.082.

Hoffmann MP, Donough CR, Cook SE, Fisher MJ, Lim CH, Lim YL, et al. 2017. Yield gap analysis in oil palm: Framework development and application in commercial operations in Southeast Asia. Agricultural Systems 151: 12-19. https://doi.org/10.1016/j.agsy.2016.11.005.

Hood WW, Wilson CS. 2001. The literature of bibliometrics, scientometrics, and informetrics. Scientometrics 52: 291-314. https://doi.org/10.1023/A:1017919924342.

Irias-Mata A, Stuetz W, Sus N, Hammann S, Gralla K, Cordero-Solano A, et. al. 2017. Tocopherols, tocomonoenols, and tocotrienols in oils of costa rican palm fruits: A comparison between six varieties and chemical versus mechanical extraction. Journal of Agricultural and Food Chemistry 65: 7476-7482. https://doi.org/10.1021/acs.jafc.7b02230.

Knowlton JL, Phifer CC, Cerqueira PV, Barro FDC, Oliveira SL, Fiser CM, et al. 2017. Oil palm plantations affect movement behavior of a key member of mixed-species flocks of forest birds in Amazonia, Brazil. Tropical Conservation Science 10: 1-10. https:// doi.org/10.1177/1940082917692800.

Lavelle P, Rodriguez N, Arguello O, Bernal J, Botero C, Chaparro P, et al. 2014. Soil ecosystem services and land use in the rapidly changing Orinoco River Basin of Colombia. Agriculture Ecosystems and Environment 185: 106-117. https://doi.org/10.1016/j. agee.2013.12.020.

Lin HW, Jin Y, Giglio L, Foley JA, Randerson JT. 2012. Evaluating greenhouse gas emissions inventories for agricultural burning using satellite observations of active fires. Ecological Applications 22: 1345-1364. https://doi.org/10.1890/10-2362.1.

Moreno-Caicedo LP, Bastidas-Pérez SE. 2017. Morphological characterization of the American oil palm collection Elaeis oleifera (Kunth) Cortés. Acta Agronómica 66: 135-140. https:// doi.org/10.15446/acag.v66n1.53819.

Murugesan P, Aswathy GM, Kumar KS, Masilamani P, Kumar V, Ravi V. 2017. Oil palm (Elaeis guineensis) genetic resources for abiotic stress tolerance: A review. Indian Journal of Agricultural Sciences 87: 571-579.
Murphy DJ. 2014. The future of oil palm as a major global crop: opportunities and challenges. Journal of Oil Palm Research 26: 1-24.

Ng SB, Ng VTD, Bock NS, Dip VNT. 2017. Method for processing oil palm fresh fruit bunches, involves separating loosened fruits from fresh fruit bunch and cleaning separated fruits prior to subsequent processing. Patent.

Ong AL, Kwong QB, Teh CK, Mohamed M, Chew FT, Appleton DR, et al. 2017. Predicting palm oil yield of test oil palm plant, comprises determining first single nucleotide polymorphism genotype of test oil palm plant from a sample, comparing to corresponding first reference SNP genotype, and predicting oil yield. Patent.

Otero-Colina G, Gonzalez-Gomez R, Martinez-Bolanos L, Otero-Prevost LG, Lopez-Buenfil JA, Escobedo-Graciamedrano RM. 2016. Infestation of Raoiella indica Hirst (Trombidiformes: Tenuipalpidae) on host plants of high socio-economic importance for tropical America. Neotropical Entomology 45: 300-309. https:// doi.org/10.1007/s13744-016-0368-z.

Pare G, Trudel MC, Jaana M, Kitsiou S. 2015. Synthesizing information systems knowledge: A typology of literature reviews. Information and Management 52: 183-199. https://doi.org/ 10.1016/j.im.2014.08.008.

Padfield R, Hansen S, Davies ZG, Ehrensperger A, Slade EM, Evers S, et al. 2019. Co-producing a research agenda for sustainable palm oil. Frontiers in Forests and Global Change 2(13). https://doi.org/ 10.3389/ffgc.2019.00013.

Rivera Mendez YD, Moreno Chacon L, Jarry Bayona C, Mauricio Romero H. 2012. Physiological response of oil palm interspecific hybrids (Elaeis oleifera HBK Cortes versus Elaeis guineensis Jacq.) to water deficit. Brazilian Journal of Plant Physiology 24: 273-280. https://doi.org/10.1590/S1677-04202012000400006.

SAGARPA. 2017. Palma de aceite mexicana. CDMX: Secretaría de Agriculura, Ganadería, Desarrollo Rural, Pesca y Alimentación (SAGARPA), $16 \mathrm{p}$.

Sandoval-Garcia AM, Reyes Altamirano-Cardenas J, Aguilar-Avila J, Garcia-Muniz JG. 2016. Chemical characterization of oil obtained by homemade methods from three african palm varieties (Elaeis guineensis Jacq.). Revista Fitotecnia Mexicana 39: 317-322. https://doi.org/10.35196/rfm.2016.3.317-322.

Scherm H, Thomas CS, Garrett KA, Olsen JM. 2014. Meta-analysis and other approaches for synthesizing structured and unstructured data in plant pathology. Annual Review of Phytopathology 52: 453 476. https://doi.org/10.1146/annurev-phyto-102313-050214.

SIAP. 2019. Cierre agricola municipal 1990-2018. In: SIAPSAGARPA (ed.) Estadística de Producción Agrícola. Ciudad de Mexico.

Sousa AS, Santos MGM, Pelacani CR, Santos FDAR. 2016. Testing culture media for pollen germination of Elaeis guineensis Jacq. (oil palm, Arecaceae). Botanical Journal of the Linnean Society 182: 536-542. https://doi.org/10.1111/boj.12404.

Woittiez LS, Van Wijk MT, Slingerland M, van Noordwijk M, Giller KE. 2017. Yield gaps in oil palm: A quantitative review of contributing factors. European Journal of Agronomy 83: 57-77. https://doi.org/10.1016/j.eja.2016.11.002.

Wyborn C, Louder E, Harrison J, Montambault J, Montana J, Ryan M, et al. 2018. Understanding the impacts of research synthesis. Environmental Science and Policy 86: 72-84. https://doi.org/ 10.1016/j.envsci.2018.04.013.

Cite this article as: Lagunes-Espinoza LC, Vazquez-Navarrete CJ, Rincón-Ramirez JA, Halvorsen KE. 2022. Oil palm crop: state and gaps of research and technological development at global scale, Latin America and Mexico. Cah. Agric. $31: 3$. 